\title{
Feed intake-dependent and -independent effects of heat stress on lactation and mammary gland development
}

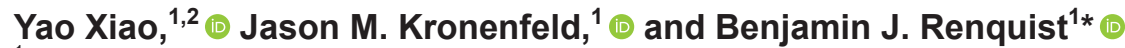 \\ ${ }^{1}$ School of Animal and Comparative Biomedical Science, University of Arizona, Tucson 85721 \\ ${ }^{2}$ Department of Animal Sciences, University of Florida, Gainesville 32611
}

\begin{abstract}
With a growing population, a reliable food supply is increasingly important. Heat stress reduces livestock meat and milk production. Genetic selection of highproducing animals increases endogenous heat production, while climate change increases exogenous heat exposure. Both sources of heat exacerbate the risk of heat-induced depression of production. Rodents are valuable models to understand mechanisms conserved across species. Heat exposure suppresses feed intake across homeothermic species including rodents and production animal species. We assessed the response to early-mid lactation or late-gestation heat exposure on milk production and mammary gland development/ function, respectively. Using pair-fed controls we experimentally isolated the feed intake-dependent and -independent effects of heat stress on mammary function and mass. Heat exposure $\left(35^{\circ} \mathrm{C}\right.$, relative humidity $50 \%$ ) decreased daily feed intake. When heat exposure occurred during lactation, hypophagia accounted for approximately $50 \%$ of the heat stress-induced hypogalactia. Heat exposure during middle to late gestation suppressed feed intake, which was fully responsible for the lowered mammary gland weight of dams at parturition. However, the impaired mammary gland function in heat-exposed dams measured by metabolic rate and lactogenesis could not be explained by depressed feed consumption. In conclusion, mice recapitulate the depressed milk production and mammary gland development observed in dairy species while providing insight regarding the role of feed intake. This opens the potential to apply genetic, experimental, and pharmacological models unique to mice to identify the mechanism by which heat is limiting animal production.
\end{abstract}

Key words: feed intake, heat stress, milk production, mouse model

Received April 7, 2020.

Accepted July 19, 2020.

*Corresponding author: bjrenquist@email.arizona.edu

\section{INTRODUCTION}

Rising global temperatures may result in global food insecurity. Heat exposure in livestock species decreases feed intake, depressing meat and milk production. Heat abatement strategies, which are largely restricted to intensive production systems, limit the losses associated with heat stress. Despite implementation of heat abatement, it was estimated in 2000 that heat-induced production losses cost the US dairy industry $\$ 897$ million (St-Pierre et al., 2003). By 2012, the dairy industry had heat-induced losses in milk production that cost the industry $\$ 1.2$ billion (Key and Sneeringer, 2014). This cost is predicted to keep rising throughout the 21st century with climate change (Gunn et al., 2019). Although the economic costs are robust, the waterintensive nature of most heat abatement strategies exacerbates the environmental impact of animal production. With water shortages common to many areas and environmental concerns of agriculture runoff, the development of approaches to limit production losses while restricting water use is essential.

The economic losses of billions of US dollars are due to depressed growth and milk production. Pair-feeding studies establish that across species the heat-induced depression in growth is nearly entirely attributable to hypophagia (O'Brien et al., 2010; Zeferino et al., 2016; Zhao et al., 2018). Thus, by understanding the mechanism behind heat-stress hypophagia, we may be able to restore growth. The decrease in milk production that results from heat exposure is multifaceted. It can be broken into short-term hypogalactia or depressed mammary development and hypophagia independent or dependent. In short-term hypogalactia $50 \%$ of the decrease in milk yield is a response to hypophagia (Rhoads et al., 2009; Wheelock et al., 2010). Heat stress during late gestation dramatically affects mammary gland development and milk production throughout lactation. The role of decreased energy intake on this muted mammary gland development has not been isolated from possible hypophagia-independent effects.

Rodents display a heat-induced reduction in feed intake that mimics that in production animal species $(\mathrm{Lu}$, 
1989; Spiers et al., 2004; Huynh et al., 2005; Morera et al., 2012; Hepler et al., 2016). Moreover, rodents recapitulate the increased sensitivity to elevated external temperature during lactation and gestation observed in high-producing dairy cows (Simons et al., 2011; Tao et al., 2011; Gantner et al., 2017). With the conservation of phenotype, the genetic, pharmacological, and surgical models available in rodents may open the door for research aimed at understanding the mechanism by which heat depresses feed intake, milk production, and late-gestation mammary development. Accordingly, we report the development of mouse models to assess the feed intake-dependent and -independent effects of heat on milk production and mammary development.

\section{MATERIALS AND METHODS}

\section{Animals}

Male and female C57BL/6J mice were purchased from The Jackson Laboratory (Bar Harbor, ME) and singly housed so that we could assess individual feed intake. Mice were maintained in a $14 \mathrm{~h}$ light, $10 \mathrm{~h}$ dark light cycle. All experimental protocols were approved by the Institutional Animal Use and Care Committee at the University of Arizona. Importantly, these studies did require single housing of this social animal and we cannot disregard the potential effect of this added stressor that was imposed across all treatments.

\section{Feed Intake Experiment}

Mice were single housed $4 \mathrm{~d}$ before treatment initiation. Control mice were housed at the control (CTL) environment $\left(22^{\circ} \mathrm{C}, 50 \%\right.$ relative humidity) and given ad libitum access to NIH-31 chow (Harlan Laboratories, Indianapolis, IN) and water. Feed and water weights were measured at 0600 and $1800 \mathrm{~h}$ daily to measure day and night consumption. Heat-stress (HS) mice were placed in a heat chamber (Coy Lab Products, Grass Lake, MI) set at $35^{\circ} \mathrm{C}$ and $50 \%$ humidity. These environmental settings have previously been shown to suppress feed intake in mice (Morera et al., 2012; Hepler et al., 2016).

\section{Lactation Experiment}

Eight-month-old multiparous females were used for these studies to ensure that mammary gland capacity was not limiting milk production. Moreover, because our measure of milk production was dependent on dams allowing the pups to suckle, these studies were run with dams that had previously nursed pups. With- in $1 \mathrm{~d}$ after parturition, litters were culled to 6 pups. Dams with a litter of only 5 pups remained on the study, whereas those with smaller litters were culled. The number of pups reared per litter was balanced between treatments. Pair-fed (PF) mice were housed in the CTL environment but fed to match feed consumed by HS mice. To match diurnal feed consumption patterns, $\sim 25 \%$ of daily feed allotment was provided to $\mathrm{PF}$ mice at $1000 \mathrm{~h}$ and $\sim 75 \%$ at $1800 \mathrm{~h}$. Feed intake, water intake, body mass, and litter mass were recorded daily at $1000 \mathrm{~h}$ from 4 to $11 \mathrm{~d}$ postpartum. Treatments (CTL, $\mathrm{n}=10$; HS, $\mathrm{n}=9$; or $\mathrm{PF}, \mathrm{n}=10$ ) began at 5 d postpartum. The weigh-suckle-weigh method was employed to assess milk production. Briefly, pups were separated from dams for $4 \mathrm{~h}$ (1000 to $1400 \mathrm{~h})$. At the end of this 4-h separation, the litter was weighed and transferred back into the original cages with the dam. After $1 \mathrm{~h}$, the litter was again weighed. The litter mass gain during the $1 \mathrm{~h}$ of suckling acted as a proxy of dam milk production.

\section{Mammary Gland Experiment}

We used 4-mo-old virgin females to assess the effect of heat stress on mammary gland development. To time breeding, 2 to 4 females were group housed for 2 wk, exposed to bedding from a male cage for $3 \mathrm{~d}$, then individually exposed to a male for $24 \mathrm{~h}$. Females remained individually housed thereafter. Females were weighed on $6,8,10$, and $12 \mathrm{~d}$ postcoitum (dpc) to assess pregnancy status. Females that displayed continuous BW gain over $2 \mathrm{~g}$ during the 6 -d period were considered pregnant (Heyne et al., 2015). Food, water, and mice were weighed daily at $1000 \mathrm{~h}$ from $13 \mathrm{dpc}$ to parturition. Treatments (CTL, $\mathrm{n}=11$; HS, $\mathrm{n}=10$; and $\mathrm{PF}, \mathrm{n}=10$ ) were initiated on $14 \mathrm{dpc}$. On the day of delivery, we assessed litter size, litter mass, and pup survival rate. Pups were killed by decapitation. Dams were killed by decapitation under isoflurane anesthesia. Pair 2, 3, 4, and 5 mammary glands were dissected and weighed as previously described.

\section{Measuring Lactogenesis of Mammary Glands}

Ex vivo mammary gland lactogenesis was measured as previously reported with minor modifications (Mellenberger et al., 1973). Pair 4 and 5 mammary glands were sliced at an average thickness of $0.2 \mathrm{~mm}$ with a microtome (Thomas Scientific, Swedesboro, NJ). Two slices of tissue from each gland were weighed and put into individual wells of a 24-well plate with $1 \mathrm{~mL}$ of Krebs-Ringer bicarbonate buffer without glucose. Slices were incubated at $37^{\circ} \mathrm{C}$ with $5 \% \mathrm{CO}_{2}$ for $0.5 \mathrm{~h}$ to al- 
low for release of endogenous lactose within the tissue. Subsequently, tissue slices were transferred into another well containing $0.5 \mathrm{~mL}$ of Krebs-Ringer bicarbonate buffer supplemented with $10 \mathrm{mM}$ glucose and $5 \mu \mathrm{g} /$ $\mathrm{mL}$ of insulin (Sigma-Aldrich, St. Louis, MO) for a 3-h incubation at $37^{\circ} \mathrm{C}$ with $5 \% \mathrm{CO}_{2}$. We collected media from the second incubation to assess lactose using a commercial assay kit (BioVision, Milpitas, CA). Lactose release into the media is reported as lactose/mg of tissue. To understand whole mammary gland lactogenic potential, we multiplied lactose/mg of tissue by whole mammary gland mass to get lactose/mammary gland.

\section{Metabolic Rates of Mammary Glands}

We used a resazurin-based assay to assess mammary gland function. Resazurin, a reagent commonly used to assess cell viability, has previously been applied to assess metabolic function in whole embryonic zebrafish and skeletal muscle biopsies (Renquist et al., 2013; Beckett et al., 2018). To our knowledge this is the first application of this measure of tissue-reducing equivalent production to assess mammary gland metabolic function. One- to 3-mg mammary tissue biopsies were isolated from mammary glands and weighed. Two biopsies from each gland were placed into $0.3 \mathrm{~mL}$ of pre-incubation medium [Dulbecco's modified Eagle's medium without glucose and phenol red (Bio5, University of Arizona, Tucson) supplemented with $1 \mathrm{mg} / \mathrm{mL}$ BSA (Sigma-Aldrich), 0.1\% dimethyl sulfoxide, and 1\% Penicillin-Streptomycin solution (Thermo Fisher Scientific, Waltham, MA)] in a 96-well plate for $0.5 \mathrm{~h}$ at $37^{\circ} \mathrm{C}$ with $5 \% \mathrm{CO}_{2}$. After a 30-min pre-incubation, tissue biopsies were transferred into the assay medium for a 4-h incubation [pre-incubation medium supplemented with $4 \mathrm{mg} / \mathrm{mL}$ glucose and $4.3 \%$ Alamar Blue solution (Bio-Rad, Hercules, CA)]. Fluorescence (excitation 530 $\mathrm{nm}$, emission $590 \mathrm{~nm}$ ) was measured at 0 and $4 \mathrm{~h}$ of incubation in the assay medium. Change in fluorescence from 0 to $4 \mathrm{~h} / \mathrm{mg}$ of tissue was calculated to understand tissue metabolic function.

\section{Statistics}

We used the mixed procedure in SAS with main effect of treatment to analyze dependent variables that we had measured at a single time point, and multiple comparisons were accounted for by Tukey's adjustment (SAS version 9.4; SAS Institute Inc., Cary, NC). When appropriate, we performed repeated measures analyses with the dependent variables being treatment, day, and their interaction. A Bonferroni correction was used to allow for multiple comparisons. Means were considered different when corrected $P$-value was less than 0.05 . Means \pm standard error of the mean were plotted using GraphPad Prism (GraphPad Software, San Diego, $\mathrm{CA})$. Throughout the manuscript, $\mathrm{n}$ is indicated in the figure legend or figure, and individual data points are used when presentation allows.

\section{RESULTS}

\section{Heat Stress Decreases Feed and Water Intake in Adult Mice}

We measured feed and water intake of adult mice housed in the CTL environment for $4 \mathrm{~d}$ (CTL; $4 \mathrm{~d}$; $22^{\circ} \mathrm{C}$, relative humidity $50 \%$ ), during $5 \mathrm{~d}$ of exposure to heat (HS; $5 \mathrm{~d} ; 35^{\circ} \mathrm{C}$, relative humidity $50 \%$ ), and again at CTL during a recovery period (CTL2; 3 d). Heat exposure decreased feed intake by $68.4 \%$ on the first day $(P<0.0001$; Figure 1A $)$ and heat continued to maintain feed intake below that seen at CTL throughout the $5 \mathrm{~d}$ of heat exposure $(P<0.05$; Figure $1 \mathrm{~A})$. Heat stress decreased average daily feed intake by $46.5 \%$ ( $P$ $<0.05$; Figure 1B). The HS decreased dark-cycle feed intake throughout the $5 \mathrm{~d}(P<0.05)$, but only affected light-cycle feed intake on the first day of heat exposure (Figures 1C and 1D).

Heat exposure less robustly affected water intake, which decreased $24.7 \%$ on the first day of HS $(P<$ 0.05 ; Figure 1E) and was not affected thereafter. Interestingly, heat did affect the diurnal pattern of water intake, decreasing water intake during the dark period and increasing water intake during the light period $(P$ $<0.05$; Figures $1 \mathrm{G}$ and $1 \mathrm{H}$ ).

\section{Heat Exposure Depresses BW and Feed and Water Intake in Lactating Female Mice}

Heat exposure and PF decreased dam mass similarly; both decreased dam mass over the first $2 \mathrm{~d}$ of treatment that was maintained during the remainder of the study $(P<0.05$; Figures 2A and 2B). Although the decrease in body mass was maximal after $2 \mathrm{~d}$ of treatment, heat exposure suppressed feed intake at all treatment days, resulting in a cumulative feed intake that was $41.6 \%$ lower than that of CTL dams $(P<0.05$; Figures $2 \mathrm{C}$ and $2 \mathrm{D})$. Heat exposure similarly decreased water intake throughout the study, resulting in a cumulative $42.2 \%$ decrease in water consumption $(P<0.05$; Figures $2 \mathrm{E}$ and $2 \mathrm{~F}$ ). Although $\mathrm{PF}$ resulted a similar depression of BW and feed intake, water intake was only mildly depressed by PF (11.1\% cumulative decrease relative to CTL). 
A

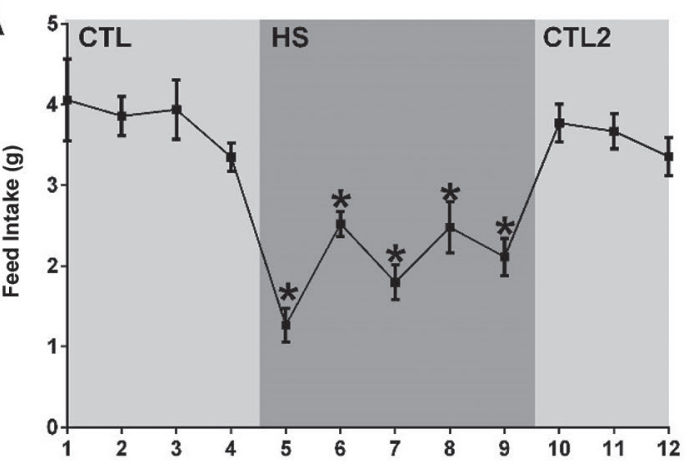

C

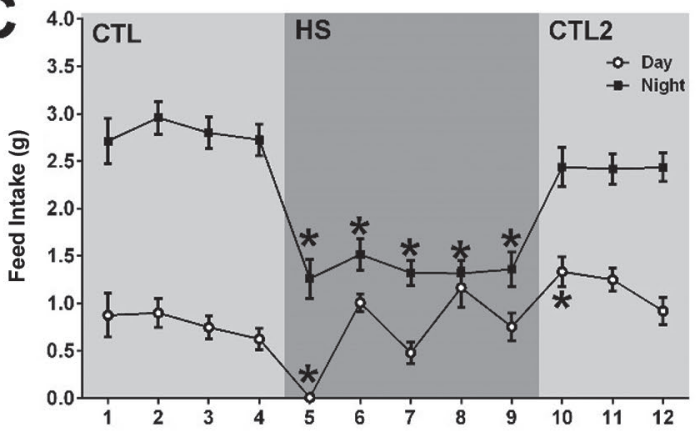

E
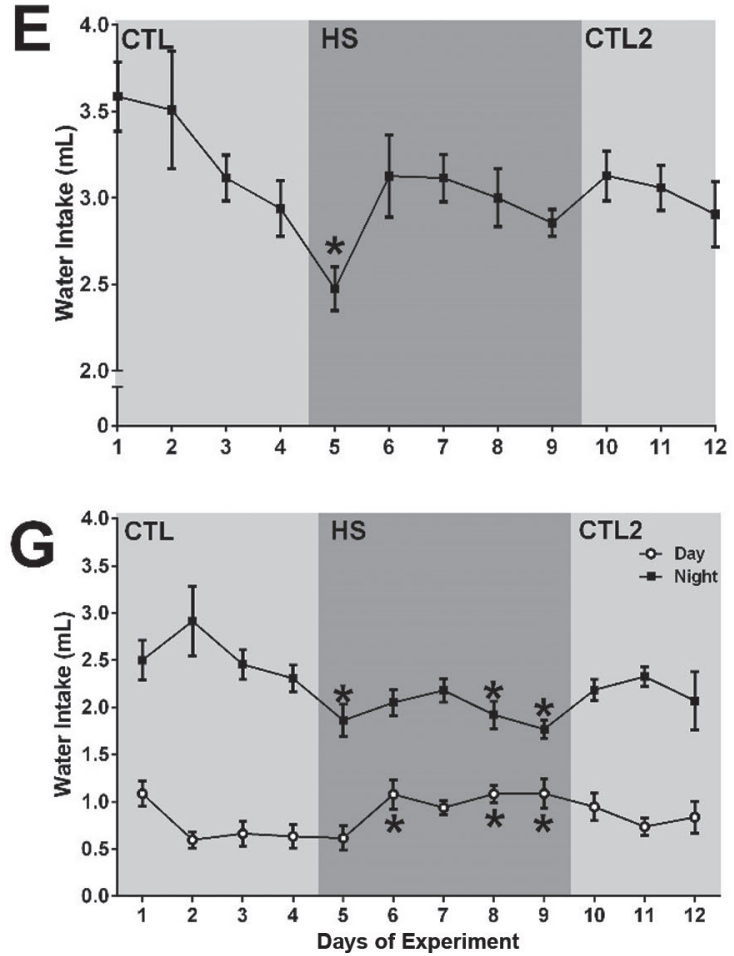

B

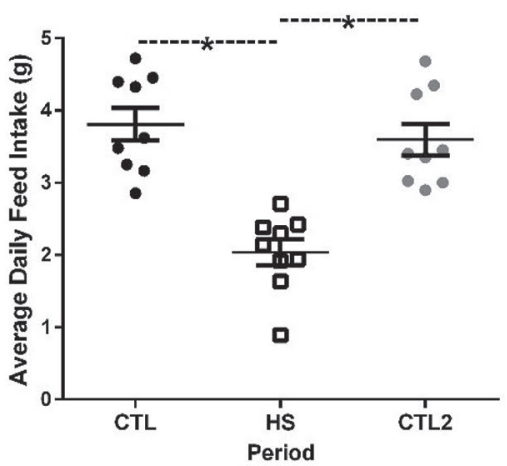

D

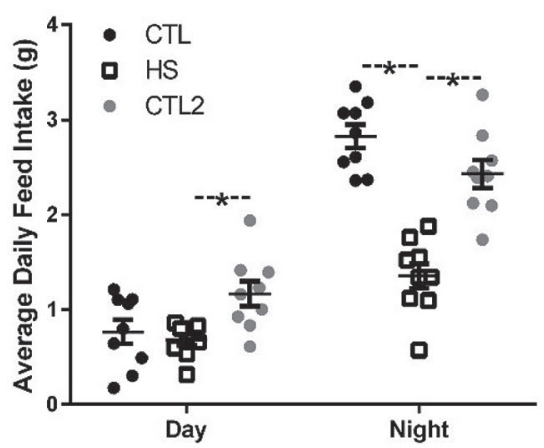

$\mathbf{F}$
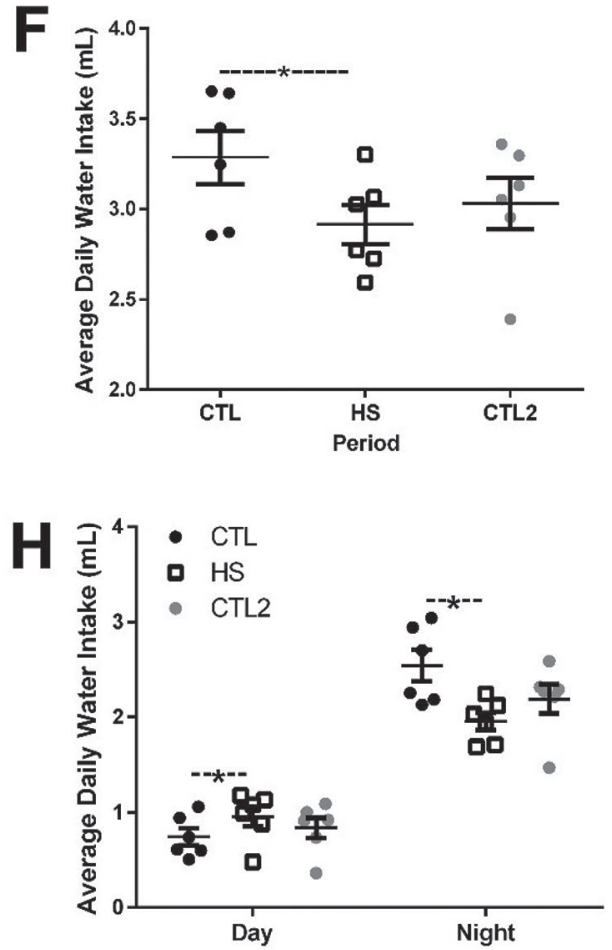

Figure 1. Food and water intake in adult mice (12-14 wk old) that were singly housed under control conditions $\left(\mathrm{CTL} ; 22^{\circ} \mathrm{C}, 50 \%\right.$ humidity) from $\mathrm{d} 1$ to 4 of the study, put in heat stress (HS; $35^{\circ} \mathrm{C}, 50 \%$ humidity) conditions from d 5 to 9, and returned to control conditions (CTL2) from d 10 to 12. (A and B) 24-h food intake, (C and D) light cycle and dark cycle food intake ( $\mathrm{n}=9,5$ female and 4 male mice), (E and F) 24-h water intake, and $(\mathrm{G}$ and $\mathrm{H})$ light cycle and dark cycle water intake $\left(\mathrm{n}=6,4\right.$ female and 2 male mice). ${ }^{*}$ indicates significant difference from mean of CTL (d 1-4; $P<0.05)$. -*- Indicates significant differences between indicated treatments $(P<0.05)$. 

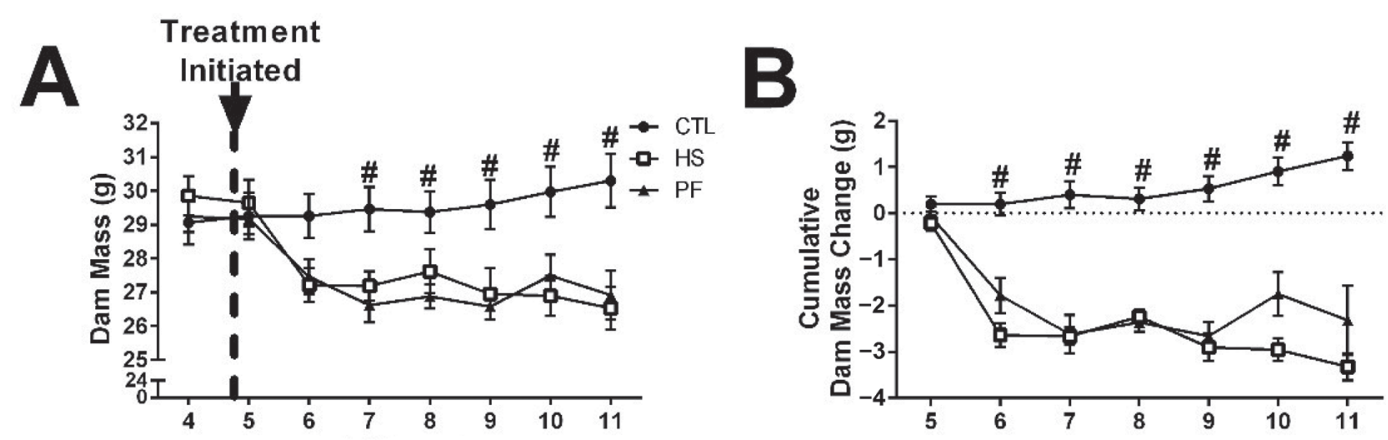

C

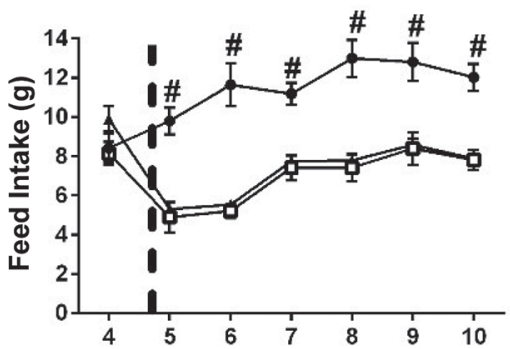

D

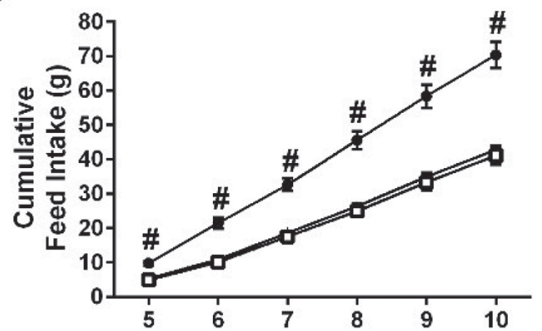

E

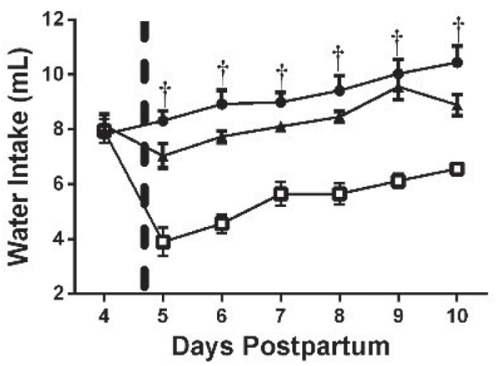

$\mathbf{F}$

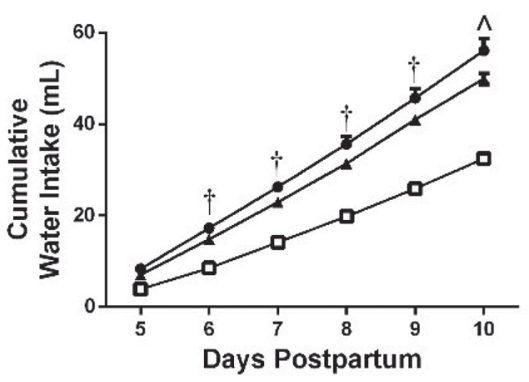

Figure 2. The response to heat stress (HS, $\mathrm{n}=9 ; 35^{\circ} \mathrm{C}, 50 \%$ humidity) and pair-feeding ( $\mathrm{PF}, \mathrm{n}=10$; fed equivalent to $\mathrm{HS}$ mice) from d 5 to 11 of lactation in multiparous dams on dam mass $(\mathrm{A}$ and $\mathrm{B})$, food intake $(\mathrm{C}$ and $\mathrm{D})$, and water intake $(\mathrm{E}$ and $\mathrm{F})$. \# CTL $($ control, $\mathrm{n}=10$; $22^{\circ} \mathrm{C}, 50 \%$ humidity) $>\mathrm{HS}$ and $\mathrm{PF}$ groups, $\dagger$ indicates $\mathrm{CTL}$ and $\mathrm{PF}>\mathrm{HS}$, and ${ }^{\wedge}$ indicates $\mathrm{CTL}>\mathrm{PF}>\mathrm{HS}(P<0.05)$.

\section{Heat Exposure During Lactation Depresses Milk Production Through Mechanisms Dependent and Independent of Feed Intake}

We evaluated the effect of heat exposure on lactation performance by assessing litter mass and performing daily weigh-suckle-weigh measurements throughout the treatment duration (Figure 3A-D). Within $2 \mathrm{~d}$, heat exposure significantly decreased cumulative litter mass gain, which remained depressed throughout the treatment period $(P<0.05$; Figure 3B). After $6 \mathrm{~d}$, litters from HS dams had gained $35 \%$ less than those from CTL dams. Pair-feeding over those $6 \mathrm{~d}$ resulted in a $20 \%$ decrease in litter mass gain, with cumulative litter mass gain significantly differing from controls from $\mathrm{d}$ 4 to 6 of treatment. Accordingly, almost $60 \%$ of the decrease in litter mass gain was explained by decreased feed intake, whereas approximately $40 \%$ of the heatinduced decrease in litter mass gain was independent of feed intake. By using a weigh-suckle-weigh method, we were able to more directly assess milk production. The first day of heat exposure (7-8 h exposure) significantly decreased weigh-suckle-weigh litter mass change $(P<$ 0.05; Figure 3C). This heat-induced depression in litter mass weight gain during a suckling bout was maintained throughout the $6 \mathrm{~d}$ of heat exposure. As we previously observed with litter mass gain, PF resulted in daily weigh-suckle-weigh measures that were intermediate to those of CTL and HS mice. By expressing the change in mass that resulted from suckling as a cumulative measure across $6 \mathrm{~d}$, we observed that HS decreased cumulative weigh-suckle-weigh mass change by $37.5 \%$ (Figure 3D), very similar to the $35 \%$ decrease in total litter mass change (Figure 3B). Pair-feeding resulted 
A

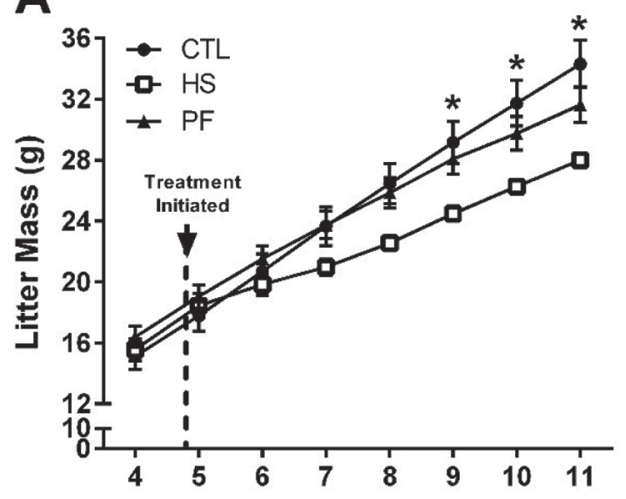

C

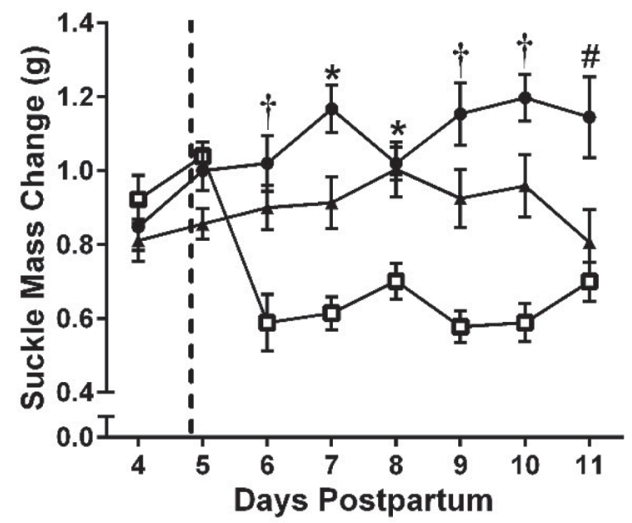

B

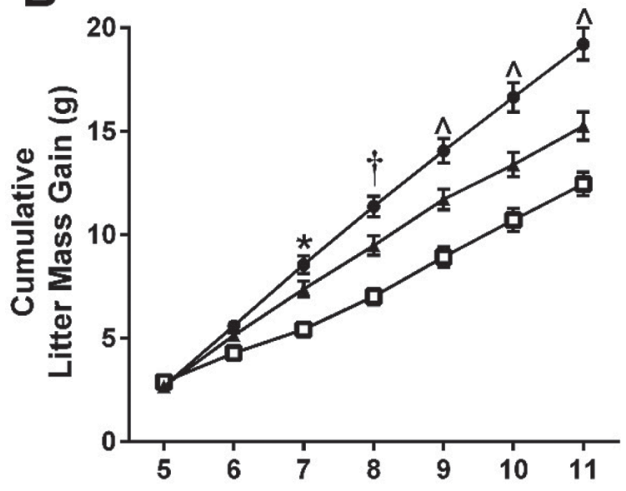

D

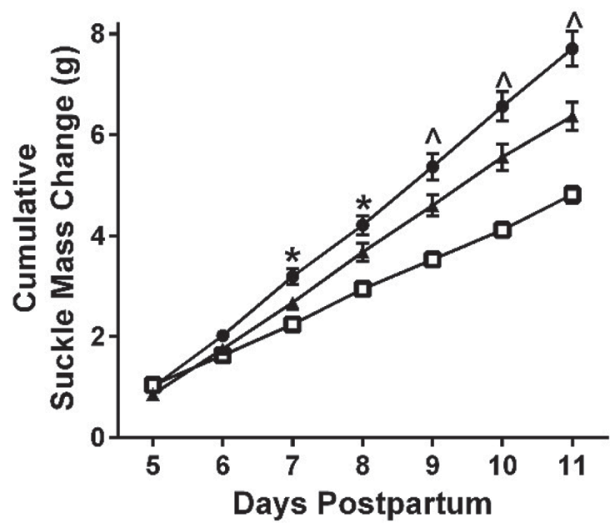

Figure 3. Litter mass (A and B) and lactation response $(\mathrm{C}$ and $\mathrm{D})$ to heat stress $\left(\mathrm{HS}, \mathrm{n}=9 ; 35^{\circ} \mathrm{C}, 50 \%\right.$ humidity) or pair-feeding $(\mathrm{PF}, \mathrm{n}=$ 10; fed equivalent to HS mice) from d 5 to 11 postpartum. $*$ indicates control (CTL, $\mathrm{n}=10 ; 22^{\circ} \mathrm{C}, 50 \%$ humidity) $>$ HS, $\dagger$ indicates $\mathrm{CTL}$ and $\mathrm{PF}>\mathrm{HS},{ }^{\wedge}$ indicates $\mathrm{CTL}>\mathrm{PF}>\mathrm{HS}$, and \# indicates $\mathrm{CTL}>\mathrm{PF}$ and HS.

in a $17.5 \%$ decrease in cumulative weigh-suckle-weigh mass change (Figure 3D), again very similar to the $20 \%$ decrease in total litter mass gain (Figure 3B). Thus, $53.3 \%$ of the heat-induced decrease in weigh-suckleweigh mass change was independent of the depression in feed intake.

\section{Heat Exposure During Late Gestation Limits BW Gain and Feed Intake Without Altering Water Consumption}

Neither HS nor PF during late gestation affected dam mass (Figure 4A). Surprisingly, PF more robustly decreased dam mass gain during late gestation (34.9\%) than did HS (18.1\%; Figure 4B).

Heat exposure decreased daily feed intake (Figure $4 \mathrm{C}$ ) on 4 out of $5 \mathrm{~d}$ and cumulative feed intake throughout the entire study $(P<0.05 ;$ Figure $4 \mathrm{D})$. In fact, heat exposure decreased cumulative feed intake by almost
40\%. Surprisingly, heat exposure only decreased water intake on the first day of treatment $(P<0.05$; Figure $4 \mathrm{E})$. Because heat did not affect water intake after the first day of exposure, heat had no effect on cumulative water intake in the end (Figure 4F). Pair-feeding lategestation dams did not alter daily or cumulative water intake (Figures $4 \mathrm{E}$ and $4 \mathrm{~F}$ ).

\section{Heat Exposure During Late Gestation Affects Litter Viability and Mean Pup Mass Without Altering Gestation Length, Litter Size, or Litter Mass}

Gestation length, litter size, and litter mass at birth were not affected by either HS or PF (Figures 5A, 5B, and 5D). However, dam heat exposure decreased pup survival $(60 \%)$ and mean pup mass $(16 \% ; P<0.05$; Figures $5 \mathrm{C}$ and $5 \mathrm{E})$. These effects on survival and pup mass are independent of feed intake, as PF did not affect either variable. 

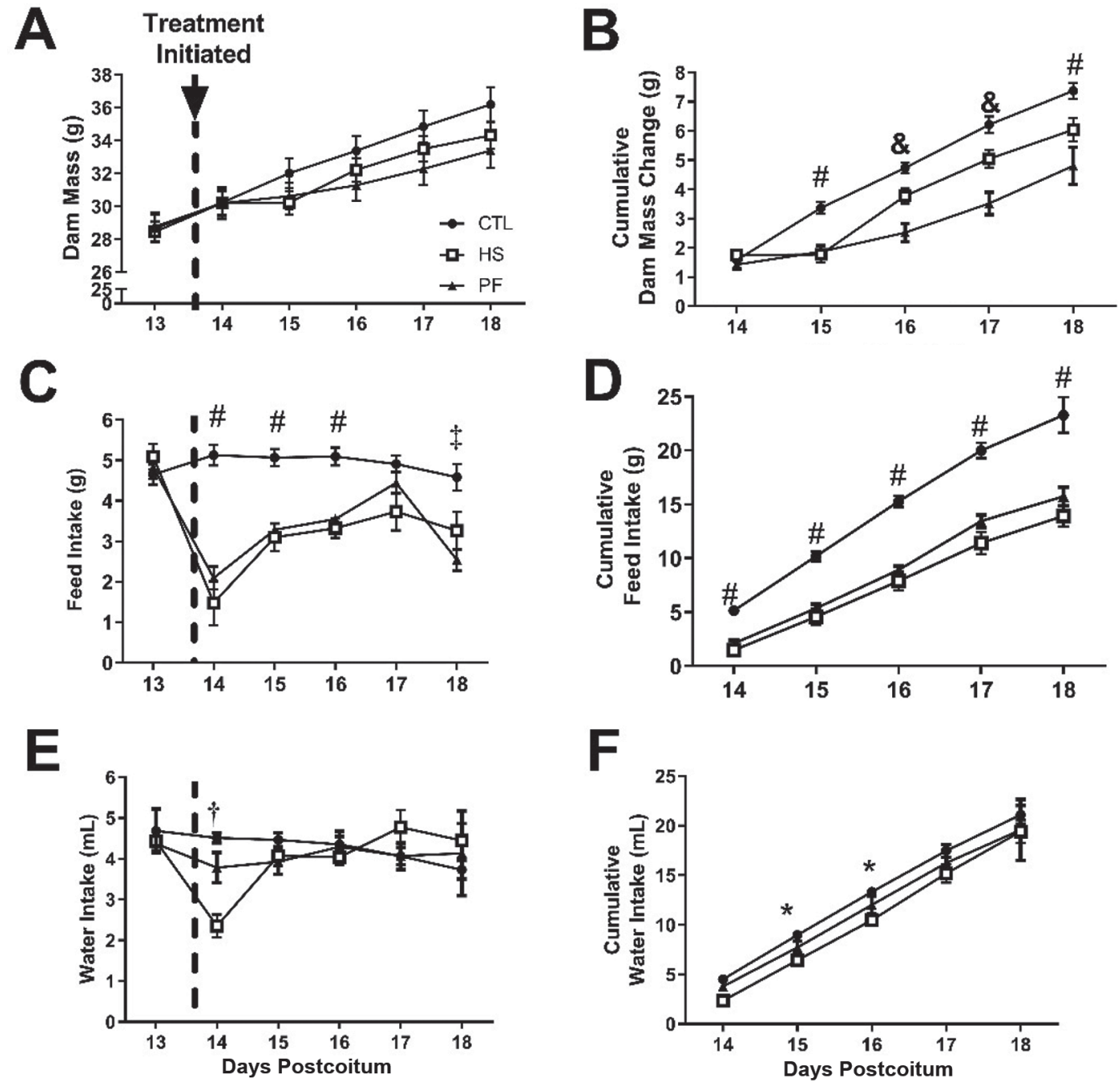

Figure 4. The effect of heat stress (HS, $\mathrm{n}=10 ; 35^{\circ} \mathrm{C}, 50 \%$ humidity) and pair-feeding (PF, $\mathrm{n}=10$; fed equivalent to $\mathrm{HS}$ mice) from $14 \mathrm{~d}$ postcoitum to parturition on dam mass $(\mathrm{A}$ and $\mathrm{B})$, food intake $(\mathrm{C}$ and $\mathrm{D})$, and water intake $(\mathrm{E}$ and $\mathrm{F})$. $^{*}$ indicates control $\left(\mathrm{CTL}, \mathrm{n}=11 ; 22^{\circ} \mathrm{C}\right.$ $50 \%$ humidity) $>\mathrm{HS}, \dagger$ indicates $\mathrm{CTL}$ and PF $>\mathrm{HS}$, \# indicates CTL $>$ PF and HS, \& indicates CTL and HS $>$ PF, and $\ddagger$ indicates CTL $>$ PF.

\section{Heat Exposure During Late Gestation Depresses Mammary Gland Mass and Function}

Heat stress and PF similarly depressed mammary gland mass at parturition $(P<0.05$; Figure $6 \mathrm{~A})$. Heat exposure during late gestation depressed the ex vivo reducing equivalent production per milligram of mammary tissue $(P<0.05)$, whereas there was no effect of PF (Figure 6B). Heat exposure during the last 5 to $6 \mathrm{~d}$ of gestation decreased ex vivo lactose production independent of the decrease in feed intake $(P<0.05$; Figure $6 \mathrm{C}$ and $6 \mathrm{D})$. In fact, $\mathrm{PF}$ did not affect either the lactose production/mg of tissue or lactose production/ gland. Accordingly, the reduction in food intake is a key component by which heat exposure decreases mammary gland mass. Still, heat affects mammary function independent of the decreased feed intake.

\section{DISCUSSION}

The hypophagic response to heat exposure is conserved across homeothermic animals, decreasing growth and product synthesis (milk, eggs) (Rhoads et al., 2009; O'Brien et al., 2010; Zhao et al., 2018; Barrett et al., 2019). We aimed to understand the hypophagia-dependent and -independent effects of heat exposure during peak lactation and late gestation on milk production and mammary gland development, respectively.

\section{Relationship Between Hypophagia and Hypogalactia Under HS Conditions}

In lactating mice, the energetic demands of lactation are robust. In fact, $44 \%$ of gross energy intake is used for milk production. To meet the energetic demand for 

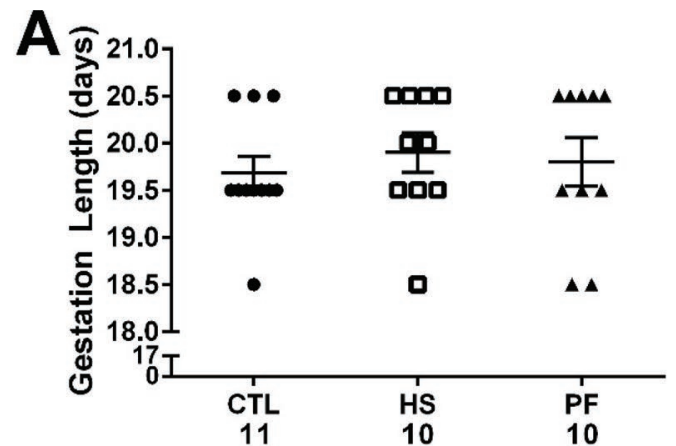

C

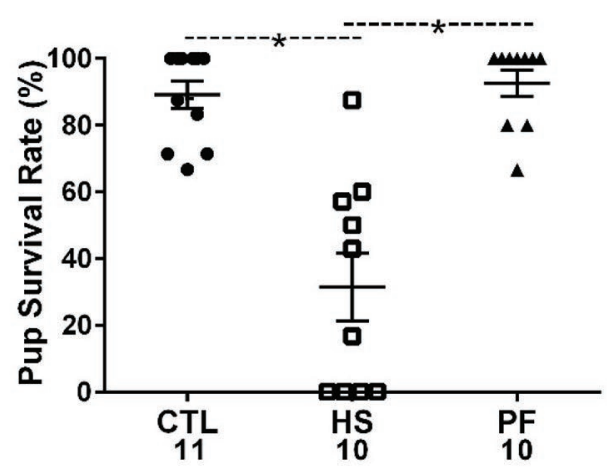

E

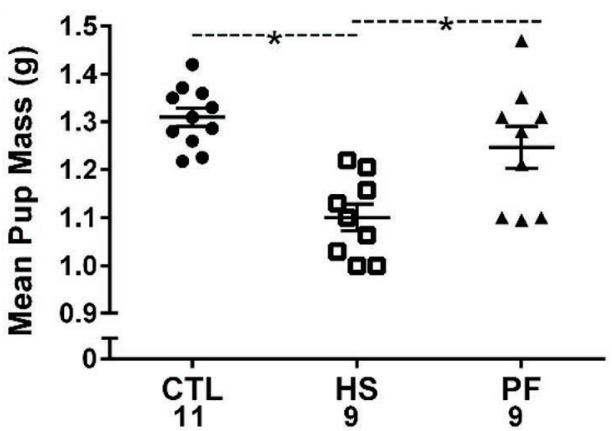

B

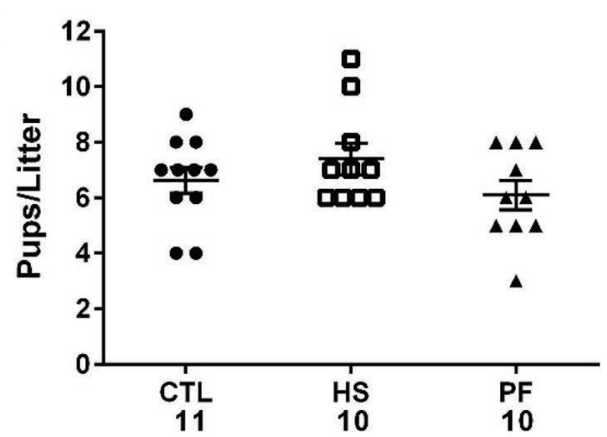

D

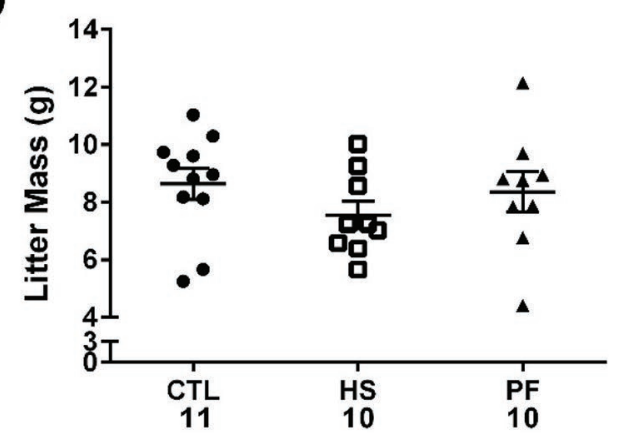

Figure 5. The effect of heat stress (HS; $35^{\circ} \mathrm{C}, 50 \%$ humidity) and pair-feeding (PF; fed equivalent to HS mice) of virgin female mice from 14 $\mathrm{d}$ postcoitum to parturition on (A) gestation length, (B) pups/litter, (C) pup survival rate, (D) litter mass, and (E) mean pup mass. CTL = control. Numbers under the treatment denote the number of biological replicates. $*$ indicates significant differences between treatments $(P<0.05)$.

lactation, lactating dam feed intake is almost 3 times higher than in nonlactating mice of similar mass and 2 times higher than in late-gestation dams. Similarly robust effects of lactation on feed intake have been reported in the $\mathrm{C} 57 \mathrm{Bl6} / \mathrm{J}$ mouse strain used here (Makarova et al., 2010). With this increased metabolic demand, our lactating dams recapitulate the increased metabolic demand in the lactating cow and the resulting increased sensitivity to exogenous heat (Collier et al., 2012). As evidence, lactation rises body temperature by $1.1^{\circ} \mathrm{C}$ in mice maintained at $21^{\circ} \mathrm{C}$, causing chronic hyperthermia (Gamo et al., 2013).

Reduced feed intake decreases the milk production across species. Consuming 32\% less energy (less than
$1,500 \mathrm{kcal} / \mathrm{d}$ ) for a week caused $15 \%$ depression in milk production in women (Strode et al., 1986). In rats, 50\% feed intake restriction leads to a $66 \%$ decrease in milk yield. Given that heat depresses feed intake, we aimed to understand the role of heat-induced hypophagia in the depression of milk production. By using litter mass gain and weigh-suckle-weigh measures as proxies for milk production, we showed that approximately $50 \%$ of heat-induced hypogalactia was independent of the heat-induced depression in feed intake. Our findings recapitulate findings in the dairy cow which have established an almost identical relative role for hypophagia $(50 \%)$ in heat-induced hypogalactia (Rhoads et al., 2009; Wheelock et al., 2010). Importantly, the de- 

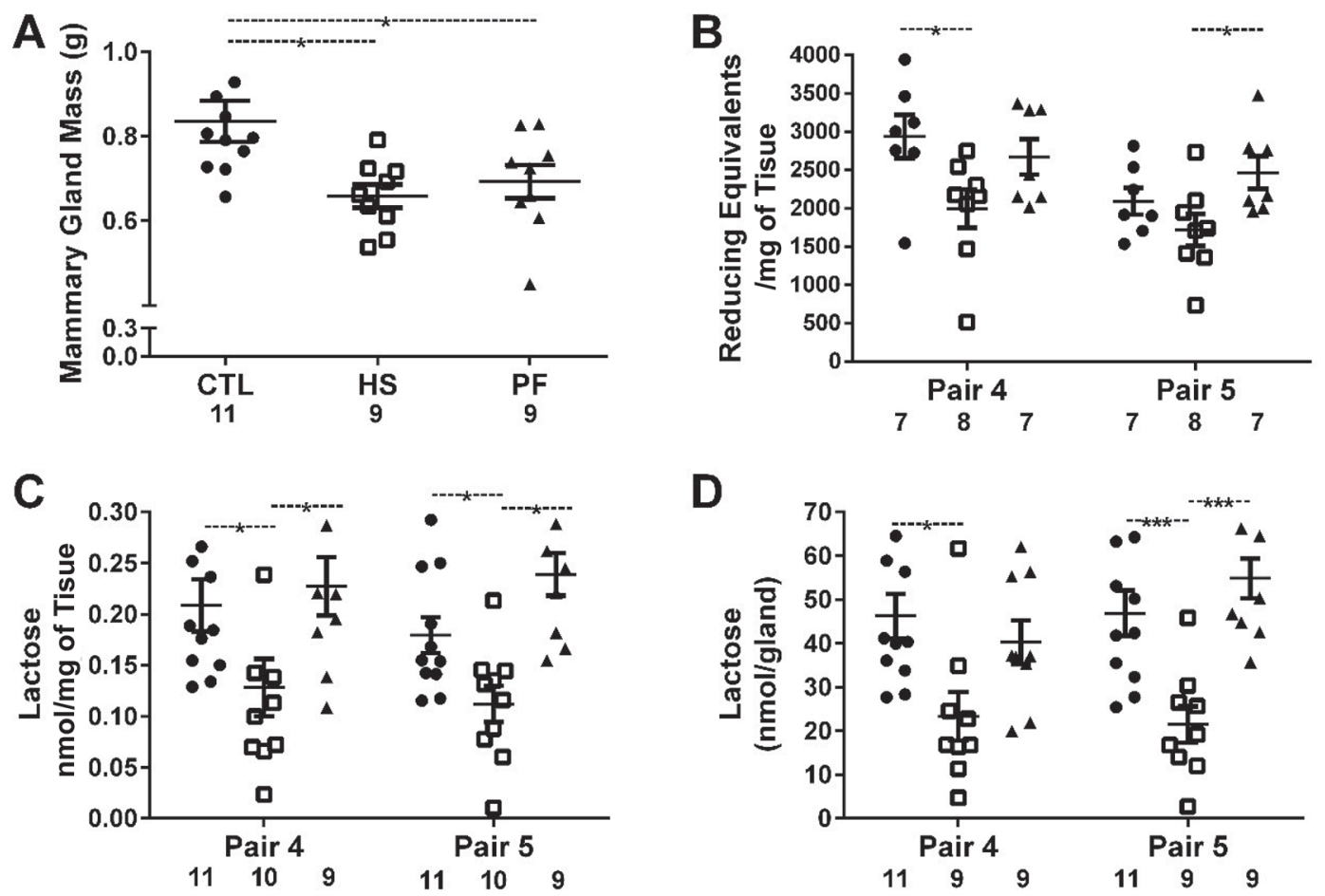

Figure 6. The effect of heat stress (HS; $35^{\circ} \mathrm{C}, 50 \%$ humidity) and pair-feeding (PF; fed equivalent to HS mice) from $14 \mathrm{~d}$ postcoitum to parturition on (A) mammary gland mass, (B) metabolic rate, (C) lactogenesis ex vivo, and (D) predicted lactose production per gland. CTL $=$ control. Numbers under the treatment denote the number of biological replicates. ${ }^{*}$ indicates significant differences between treatments $(P<$ $0.05),{ }^{* * *} P<0.001$.

creased mass of the pups and decreased weight change during weigh-suckle-weigh is not due to heat stress in the pups. Mouse pups from 1 to $16 \mathrm{~d}$ of age, when tested in a temperature gradient, prefer temperatures $>35^{\circ} \mathrm{C}$ (Ogilvie and Stinson, 1966; Eedy and Ogilvie, 1970).

\section{Heat Exposure Impairs Mammary Gland Weight and Mammary Function Through Divergent Mechanisms}

From late gestation through early lactation, there is robust mammary gland expansion through proliferation (Lu and Anderson, 1973; Knight and Peaker, 1982; Howard and Gusterson, 2000; Sørensen et al., 2002). Late-gestation heat stress limits mammary gland development, depressing milk production throughout lactation (Tao et al., 2011; Dado-Senn et al., 2019; Hooper et al., 2020). This depression in milk production that lasts the entire lactation is economically disastrous.

Heat exposure during late gestation decreased dam weight gain (Figure 4A) as previously observed in the dairy cow. Heat-exposed dams tended to gain more weight than PF dams (Figure 4B). This is likely because $\mathrm{PF}$ mice housed at $22^{\circ} \mathrm{C}$ were expending significantly more energy to maintain body temperature, almost $0.2 \mathrm{kcal} / \mathrm{h}$ per mouse or $150 \%$ of that expended by mice housed in thermoneutral housing conditions (Gordon, 2012). Energy expenditure of mice is linearly increased when ambient temperatures decreased from $30^{\circ} \mathrm{C}$ to $22^{\circ} \mathrm{C}$ (Abreu-Vieira et al., 2015; Keijer et al., 2019 ). At $35^{\circ} \mathrm{C}$ there is a mild increase in energy expenditure relative to mice housed at 28 to $32^{\circ} \mathrm{C}$. However, this increased metabolic rate is only a fraction of that observed in mice reared at $22^{\circ} \mathrm{C}$ (Pennycuik, 1967).

We found gestational heat exposure caused a $20 \%$ reduction in mammary gland weight at parturition. Indeed, mammary cell proliferation, but not apoptosis, is vulnerable to thermal stress during pregnancy (Tao et al., 2011). Feed intake and BW gain during pregnancy are both associated with mammary gland DNA content (Kumaresan and Turner, 1968). We found that $\mathrm{PF}$ recapitulated the impaired mammary growth that we observed in heat-exposed animals (Figure 6A). Mammary gland function measured as mammary gland mitochondrial activity and lactose production were impaired by heat exposure (Figure 6B-6C). The disrupted mammary gland function caused by late-gestation heat stress may be a result of altered tissue composition, as mammary glands from heat-exposed cows have fewer alveoli and more connective tissue (Dado-Senn et al., 2019). In addition, heat exposure during late gesta- 
tion altered mRNA expression of enzymes increasing acetyl CoA carboxylase and fatty acid synthase, while decreasing expression of mRNA for the key lipolytic enzyme, hormone sensitivity lipase (Adin et al., 2009). Importantly, the heat-induced loss in mammary function was not recapitulated by $\mathrm{PF}$.

\section{Heat Exposure Fetal Growth}

Late-gestation heat stress has been reported to either shorten or not affect gestation length across species (Collier et al., 1982; Porter et al., 1999; Tao et al., 2012; Williams et al., 2013). We found no effect of gestational heat stress on gestation length in mice. However, we did observe that late-gestation heat stress depressed neonatal mass and survival. In fact, pup mass decreased $(17.1 \pm 4.7 \%)$ well within the range of 6 to $30 \%$ that has been previously reported and was compiled in a review by Tao and Dahl (2013). This decreased prenatal growth in response to gestational heat stress is thought to result from decreased placental mass, placentomes, and umbilical blood flow (Collier et al., 1982; Reynolds et al., 1985; Alexander et al., 1987; Bell et al., 1989; Early et al., 1991). Because we observed normal fetal growth in PF dams, nutrient accessibility to the fetus rather than nutrient intake by the dam is likely mediating this fetal restriction. Depressed fetal development may negatively affect subsequent performance of the offspring. In fact, in utero heat stress has been shown to depress milk production and mammary gland structure in the offspring's first lactation (Monteiro et al., 2016; Skibiel et al., 2018; Dado-Senn et al., 2019).

\section{Conserved and Divergent Water Consumption Response to Heat Stress in Mice and Cattle}

Surprisingly, we noted that our HS male mice drank less water than their CTL counterparts. This is in direct contradiction with findings in the cow, which show that heat stress drives lactating cows to consume more water (McDowell et al., 1969). There are multiple hypotheses that could explain these divergent findings. First, feed and water intake are inextricably linked in mice. Accordingly, treatments that decrease feed intake will depress water intake. Across mouse species, food intake is a closely linked to water consumption $(67 \%$ of variation in water consumption across mouse strains is explained by variation in feed consumption). In turn, it should be noted that water intake was increased during the light hours and decreased during the dark hours during heat stress. In addition to this shift in diurnal water intake, a similar shift occurred in the diurnal eating pattern. A robust decrease occurred in dark cycle feeding as well as an apparent maintenance of light-cycle food intake. Accordingly, this supports the hypothesis that feed intake was driving the decreased water intake during heat stress. Second, C57BL mice that were used in this study consume much less water than other strains of mice and may not be a suitable model to understand water balance (Magee et al., 2017). Third, mice rely much less on evaporative heat loss than larger species. Because mice are small, the surface area to volume ratio is much greater than that in production species. This greater surface area allows the mouse to easily lose heat to the environment and decreases the need for evaporative cooling. Accordingly, sweat glands are restricted to the footpads in mice $(\mathrm{Lu}$ and Fuchs, 2014), whereas sweat glands are widely distributed throughout the skin of cattle (Jenkinson et al., 1979) and these sweat glands are highly responsive to external temperatures (Dikmen et al., 2008; Zimbelman et al., 2010). With less water loss associated with cooling, rodents may not be a good model to study water balance under heat stress conditions. Importantly, as we show in the lactating mouse, water consumption does decrease in the high-producing cow in response to heat exposure (Collier et al., 2019). This is likely due to the decreased water demand for milk production.

Our studies establish that the mouse recapitulates the heat stress phenotypes observed in production animals. These include depressed feed intake, decreased lactation that is both dependent and independent of feed intake, and depressed mammary gland development. Using this mouse model, we observed the novel finding that heat-induced depression of mammary gland mass was completely attributable to depressed feed intake, whereas the decreased mammary function was entirely independent of hypophagia. Our late-gestation heat exposure caused restricted fetal growth, which is similar to that observed in farm animals (Tao and Dahl, 2013; Monteiro et al., 2016; Laporta et al., 2017). These in utero effects were independent of changes in feed consumption. Together, our data validate these mouse models as valuable tools for studying the physiological responses to heat stress, thereby opening the door for mechanistic studies using genetic and pharmacologic models to identify the mechanism by which heat exposure causes these physiological changes.

\section{ACKNOWLEDGMENTS}

This article is based upon work that is supported by the National Institute of Food and Agriculture (Washington, DC), U.S. Department of Agriculture, under award number 2015-06367 (B. J. Renquist). The authors declare no competing or financial interests. 


\section{REFERENCES}

Abreu-Vieira, G., C. Xiao, O. Gavrilova, and M. L. Reitman. 2015. Integration of body temperature into the analysis of energy expenditure in the mouse. Mol. Metab. 4:461-470. https://doi.org/10 .1016/j.molmet.2015.03.001.

Adin, G., A. Gelman, R. Solomon, I. Flamenbaum, M. Nikbachat, E. Yosef, A. Zenou, A. Shamay, Y. Feuermann, S. J. Mabjeesh, and J. Miron. 2009. Effects of cooling dry cows under heat load conditions on mammary gland enzymatic activity, intake of food and water, and performance during the dry period and after parturition. Livest. Sci. 124:189-195. https://doi.org/10.1016/j.livsci 2009.01.014.

Alexander, G., J. R. Hales, D. Stevens, and J. B. Donnelly. 1987. Effects of acute and prolonged exposure to heat on regional blood flows in pregnant sheep. J. Dev. Physiol. 9:1-15.

Barrett, N. W., K. Rowland, C. J. Schmidt, S. J. Lamont, M. F. Rothschild, C. M. Ashwell, and M. E. Persia. 2019. Effects of acute and chronic heat stress on the performance, egg quality, body temperature, and blood gas parameters of laying hens. Poult. Sci. 98:6684-6692. https://doi.org/10.3382/ps/pez541.

Beckett, L., R. Rosemond, B. Renquist, and R. R. White. 2018. Evaluating a novel strategy for measuring basal metabolic rate of bovine skeletal muscle. J. Anim. Sci. 96(suppl_1):47-48.

Bell, A. W., B. W. McBride, R. Slepetis, R. J. Early, and W. B. Currie. 1989. Chronic heat stress and prenatal development in sheep: I. Conceptus growth and maternal plasma hormones and metabolites. J. Anim. Sci. 67:3289-3299. https://doi.org/10.2527/jas1989 $.67123289 x$.

Collier, R. J., L. H. Baumgard, R. B. Zimbelman, and Y. Xiao. 2019. Heat stress: Physiology of acclimation and adaptation. Anim. Front. 9:12-19. https://doi.org/10.1093/af/vfy031.

Collier, R. J., S. G. Doelger, H. H. Head, W. W. Thatcher, and C. J. Wilcox. 1982. Effects of heat stress during pregnancy on maternal hormone concentrations, calf birth weight and postpartum milk yield of Holstein cows. J. Anim. Sci. 54:309-319. https://doi.org/ $10.2527 /$ jas1982.542309x.

Collier, R. J., L. W. Hall, S. Rungruang, and R. Zimbleman. 2012. Quantifying heat stress and its impact on metabolism and performance. Pages 74-83 in Proc. Florida Ruminant Nutrition Symp., Gainesville. University of Florida, Gainesville.

Dado-Senn, B., A. L. Skibiel, T. F. Fabris, G. E. Dahl, and J. Laporta. 2019. Dry period heat stress induces microstructural changes in the lactating mammary gland. PLoS One 14:e0222120. https://doi .org/10.1371/journal.pone.0222120.

Dikmen, S., E. Alava, E. Pontes, J. M. Fear, B. Y. Dikmen, T. A. Olson, and P. J. Hansen. 2008. Differences in thermoregulatory ability between slick-haired and wild-type lactating Holstein cows in response to acute heat stress. J. Dairy Sci. 91:3395-3402. https: //doi.org/10.3168/jds.2008-1072.

Early, R. J., B. W. McBride, I. Vatnick, and A. W. Bell. 1991. Chronic heat stress and prenatal development in sheep: II. Placental cellularity and metabolism. J. Anim. Sci. 69:3610-3616. https://doi .org/10.2527/1991.6993610x.

Eedy, J. W., and D. M. Ogilvie. 1970. The effect of age on the thermal preference of white mice (Mus musculus) and gerbils (Meriones unguiculatus). Can. J. Zool. 48:1303-1306. https://doi.org/10.1139/ z70-221.

Gamo, Y., C. Troup, S. E. Mitchell, C. Hambly, L. M. Vaanholt, and J. R. Speakman. 2013. Limits to sustained energy intake. XX. Body temperatures and physical activity of female mice during lactation. J. Exp. Biol. 216:3751-3761. https://doi.org/10.1242/ jeb.090308.

Gantner, V., T. Bobic, R. Gantner, M. Gregic, K. Kuterovac, J. Novakovic, and K. Potocnik. 2017. Differences in response to heat stress due to production level and breed of dairy cows. Int. J. Biometeorol. 61:1675-1685. https://doi.org/10.1007/s00484-017-1348-7.

Gordon, C. 2012. Thermal physiology of laboratory mice: Defining thermoneutrality. J. Therm. Biol. 37:654-685. https://doi.org/10 $.1016 / \mathrm{j}$.jtherbio.2012.08.004.
Gunn, K. M., M. A. Holly, T. L. Veith, A. R. Buda, R. Prasad, C. A. Rotz, K. J. Soder, and A. M. K. Stoner. 2019. Projected heat stress challenges and abatement opportunities for U.S. milk production. PLoS One 14:e0214665. https://doi.org/10.1371/journal .pone.0214665.

Hepler, C., C. E. Foy, M. R. Higgins, and B. J. Renquist. 2016. The hypophagic response to heat stress is not mediated by GPR109A or peripheral beta-OH butyrate. Am. J. Physiol. Regul. Integr. Comp. Physiol. 310:R992-R998. https://doi.org/10.1152/ajpregu .00513 .2015 .

Heyne, G. W., E. H. Plisch, C. G. Melberg, E. P. Sandgren, J. A. Peter, and R. J. Lipinski. 2015. A simple and reliable method for early pregnancy detection in inbred mice. J. Am. Assoc. Lab. Anim. Sci. 54:368-371.

Hooper, H. B., P. D. S. Silva, S. A. de Oliveira, G. K. F. Meringhe, P. Lacasse, and J. A. Negrao. 2020. Effect of heat stress in late gestation on subsequent lactation performance and mammary cell gene expression of Saanen goats. J. Dairy Sci. 103:1982-1992. https:// doi.org/10.3168/jds.2019-16734.

Howard, B. A., and B. A. Gusterson. 2000. Human breast development. J. Mammary Gland Biol. Neoplasia 5:119-137. https://doi .org/10.1023/A:1026487120779.

Huynh, T. T., A. J. Aarnink, M. W. Verstegen, W. J. Gerrits, M. J. Heetkamp, B. Kemp, and T. T. Canh. 2005. Effects of increasing temperatures on physiological changes in pigs at different relative humidities. J. Anim. Sci. 83:1385-1396. https://doi.org/10.2527/ 2005.8361385x.

Jenkinson, D. M., I. Montgomery, and H. Y. Elder. 1979. The ultrastructure of the sweat glands of the ox, sheep and goat during sweating and recovery. J. Anat. 129:117-140.

Keijer, J., M. Li, and J. R. Speakman. 2019. What is the best housing temperature to translate mouse experiments to humans? Mol Metab. 25:168-176. https://doi.org/10.1016/j.molmet.2019.04 .001 .

Key, N., and S. Sneeringer. 2014. Potential effects of climate change on the productivity of U.S. dairies. Am. J. Agric. Econ. 96:1136-1156. https://doi.org/10.1093/ajae/aau002.

Knight, C. H., and M. Peaker. 1982. Mammary cell proliferation in mice during pregnancy and lactation in relation to milk yield. Q. J. Exp. Physiol. 67:165-177. https://doi.org/10.1113/expphysiol .1982.sp002610.

Kumaresan, P., and C. W. Turner. 1968. Effect of pregnancy on feed consumption and mammary gland growth in rats. Proc. Soc. Exp. Biol. Med. 129:957-960. https://doi.org/10.3181/00379727-129 -33467 .

Laporta, J., T. F. Fabris, A. L. Skibiel, J. L. Powell, M. J. Hayen, K. Horvath, E. K. Miller-Cushon, and G. E. Dahl. 2017. In utero exposure to heat stress during late gestation has prolonged effects on the activity patterns and growth of dairy calves. J. Dairy Sci. 100:2976-2984. https://doi.org/10.3168/jds.2016-11993.

Lu, C., and E. Fuchs. 2014. Sweat gland progenitors in development, homeostasis, and wound repair. Cold Spring Harb. Perspect. Med. 4:a015222. https://doi.org/10.1101/cshperspect.a015222.

$\mathrm{Lu}$, C. D. 1989. Effects of heat stress on goat production. Small Rumin. Res. 2:151-162. https://doi.org/10.1016/0921-4488(89)90040 -0 .

Lu, M. H., and R. R. Anderson. 1973. Growth of the mammary gland during pregnancy and lactation in the rabbit. Biol. Reprod. 9:538543. https://doi.org/10.1093/biolreprod/9.5.538.

Magee, D., M. T. Haag, S. B. Johnson, C. Rosenfeld, K. D. Wells, and W. R. Lamberson. 2017. Cognitive ability, activity, and metabolic rate in mice divergent for water consumption. J. Anim. Sci. 95(suppl_2):190.

Makarova, E. N., E. D. Kochubei, and N. M. Bazhan. 2010. Regulation of food consumption during pregnancy and lactation in mice. Neurosci. Behav. Physiol. 40:263-267. https://doi.org/10.1007/ s11055-010-9253-0.

McDowell, R. E., E. G. Moody, P. J. Van Soest, R. P. Lehmann, and G. L. Ford. 1969. Effect of heat stress on energy and water utiliza- 
tion of lactating cows. J. Dairy Sci. 52:188-194. https://doi.org/10 .3168/jds.S0022-0302(69)86528-8.

Mellenberger, R. W., D. E. Bauman, and D. R. Nelson. 1973. Metabolic adaptations during lactogenesis. Fatty acid and lactose synthesis in cow mammary tissue. Biochem. J. 136:741-748. https:// doi.org/10.1042/bj1360741.

Monteiro, A. P. A., S. Tao, I. M. T. Thompson, and G. E. Dahl. 2016. In utero heat stress decreases calf survival and performance through the first lactation. J. Dairy Sci. 99:8443-8450. https://doi .org/10.3168/jds.2016-11072.

Morera, P., L. Basirico, K. Hosoda, and U. Bernabucci. 2012. Chronic heat stress up-regulates leptin and adiponectin secretion and expression and improves leptin, adiponectin and insulin sensitivity in mice. J. Mol. Endocrinol. 48:129-138. https://doi.org/10.1530/ JME-11-0054.

O'Brien, M. D., R. P. Rhoads, S. R. Sanders, G. C. Duff, and L. H. Baumgard. 2010. Metabolic adaptations to heat stress in growing cattle. Domest. Anim. Endocrinol. 38:86-94. https://doi.org/10 .1016/j.domaniend.2009.08.005.

Ogilvie, D. M., and R. H. Stinson. 1966. The effect of age on temperature selection by laboratory mice (Mus musculus). Can. J. Zool. 44:511-517. https://doi.org/10.1139/z66-055.

Pennycuik, P. R. 1967. A comparison of the effects of a variety of factors on the metabolic rate of the mouse. Aust. J. Exp. Biol. Med. Sci. 45:331-346. https://doi.org/10.1038/icb.1967.33.

Porter, K. R., S. D. Thomas, and S. Whitman. 1999. The relation of gestation length to short-term heat stress. Am. J. Public Health 89:1090-1092. https://doi.org/10.2105/AJPH.89.7.1090.

Renquist, B. J., C. Zhang, S. Y. Williams, and R. D. Cone. 2013. Development of an assay for high-throughput energy expenditure monitoring in the zebrafish. Zebrafish 10:343-352. https://doi .org/10.1089/zeb.2012.0841.

Reynolds, L. P., C. L. Ferrell, J. A. Nienaber, and S. P. Ford. 1985. Effects of chronic environmental heat stress on blood flow and nutrient uptake of the gravid bovine uterus and foetus. J. Agric. Sci. 104:289-297. https://doi.org/10.1017/S002185960004394X.

Rhoads, M. L., R. P. Rhoads, M. J. VanBaale, R. J. Collier, S. R. Sanders, W. J. Weber, B. A. Crooker, and L. H. Baumgard. 2009. Effects of heat stress and plane of nutrition on lactating Holstein cows: I. Production, metabolism, and aspects of circulating somatotropin. J. Dairy Sci. 92:1986-1997. https://doi.org/10.3168/ jds.2008-1641.

Simons, M. J., I. Reimert, V. van der Vinne, C. Hambly, L. M. Vaanholt, J. R. Speakman, and M. P. Gerkema. 2011. Ambient temperature shapes reproductive output during pregnancy and lactation in the common vole (Microtus arvalis): A test of the heat dissipation limit theory. J. Exp. Biol. 214:38-49. https://doi.org/ 10.1242 /jeb.044230.

Skibiel, A. L., B. Dado-Senn, T. F. Fabris, G. E. Dahl, and J. Laporta. 2018. In utero exposure to thermal stress has long-term effects on mammary gland microstructure and function in dairy cattle. PLoS One 13:e0206046. https://doi.org/10.1371/journal.pone.0206046.

Sørensen, M. T., K. Sejrsen, and S. Purup. 2002. Mammary gland development in gilts. Livest. Prod. Sci. 75:143-148. https://doi.org/ 10.1016/S0301-6226(01)00310-4.
Spiers, D. E., J. N. Spain, J. D. Sampson, and R. P. Rhoads. 2004. Use of physiological parameters to predict milk yield and feed intake in heat-stressed dairy cows. J. Therm. Biol. 29:759-764. https://doi .org/10.1016/j.jtherbio.2004.08.051.

St-Pierre, N. R., B. Cobanov, and G. Schnitkey. 2003. Economic losses from heat stress by US livestock industries. J. Dairy Sci. 86:E52E77. https://doi.org/10.3168/jds.S0022-0302(03)74040-5.

Strode, M. A., K. G. Dewey, and B. Lonnerdal. 1986. Effects of shortterm caloric restriction on lactational performance of well-nourished women. Acta Paediatr. Scand. 75:222-229. https://doi.org/ 10.1111/j.1651-2227.1986.tb10188.x.

Tao, S., J. W. Bubolz, B. C. do Amaral, I. M. Thompson, M. J. Hayen, S. E. Johnson, and G. E. Dahl. 2011. Effect of heat stress during the dry period on mammary gland development. J. Dairy Sci. 94:5976-5986. https://doi.org/10.3168/jds.2011-4329.

Tao, S., and G. E. Dahl. 2013. Invited review: Heat stress effects during late gestation on dry cows and their calves. J. Dairy Sci. 96:4079-4093. https://doi.org/10.3168/jds.2012-6278.

Tao, S., I. M. Thompson, A. P. A. Monteiro, M. J. Hayen, L. J. Young, and G. E. Dahl. 2012. Effect of cooling heat-stressed dairy cows during the dry period on insulin response. J. Dairy Sci. 95:50355046. https://doi.org/10.3168/jds.2012-5405.

Wheelock, J. B., R. P. Rhoads, M. J. Vanbaale, S. R. Sanders, and L. H. Baumgard. 2010. Effects of heat stress on energetic metabolism in lactating Holstein cows. J. Dairy Sci. 93:644-655. https://doi .org/10.3168/jds.2009-2295.

Williams, A. M., T. J. Safranski, D. E. Spiers, P. A. Eichen, E. A. Coate, and M. C. Lucy. 2013. Effects of a controlled heat stress during late gestation, lactation, and after weaning on thermoregulation, metabolism, and reproduction of primiparous sows. J Anim. Sci. 91:2700-2714. https://doi.org/10.2527/jas.2012-6055.

Zeferino, C. P., C. M. Komiyama, V. C. Pelicia, V. B. Fascina, M. M. Aoyagi, L. L. Coutinho, J. R. Sartori, and A. S. Moura. 2016. Carcass and meat quality traits of chickens fed diets concurrently supplemented with vitamins $\mathrm{C}$ and $\mathrm{E}$ under constant heat stress. Animal 10:163-171. https://doi.org/10.1017/S1751731115001998.

Zhao, L., R. P. McMillan, G. Xie, S. Giridhar, L. H. Baumgard, S. El-Kadi, J. Selsby, J. Ross, N. Gabler, M. W. Hulver, and R. P. Rhoads. 2018. Heat stress decreases metabolic flexibility in skeletal muscle of growing pigs. Am. J. Physiol. Regul. Integr. Comp. Physiol. 315:R1096-R1106. https://doi.org/10.1152/ajpregu .00404 .2017 .

Zimbelman, R. B., L. H. Baumgard, and R. J. Collier. 2010. Effects of encapsulated niacin on evaporative heat loss and body temperature in moderately heat-stressed lactating Holstein cows. J. Dairy Sci. 93:2387-2394. https://doi.org/10.3168/jds.2009-2557.

\section{ORCIDS}

Yao Xiao 으 https://orcid.org/0000-0002-5153-6839

Jason M. Kronenfeld ๑ https://orcid.org/0000-0002-3026-2736

Benjamin J. Renquist ( https://orcid.org/0000-0003-1517-8226 